\title{
平行カルダン駆動電気鉄道車両の主電動機トルクによる車体振動制御*
}

\author{
牧島 信吾 ${ }^{* 1}$, 永井 正夫 ${ }^{* 2}$
}

\section{Vibration Control of Railway Vehicle with Parallel Cardan Drives by Traction Motor Torques}

\author{
Shingo MAKISHIMA *1 and Masao NAGAI \\ ${ }^{* 1}$ Toyo Denki Seizo K. K. \\ 3-8, Fukuura, Kanazawa-ku, Yokohama, Kanagawa
}

\begin{abstract}
This paper presents a method to suppress the vertical bending vibration of electric railcar by using traction motor. Dynamics of the truck with parallel cardan drives can be controlled by torque of the traction motors. This paper proposes a control method to reduce vertical vibration of truck frame by the traction motor torques to reduce car-body vibration. The motor torques are added with the traction torques of the control scheme in reverse phase for two traction motors of a truck. Experimental result shows that the control method using traction motor torque can decrease the truck frame vibration.
\end{abstract}

Key Words : Railway, Vehicle Dynamics, Vibration of Moving Body, Vibration Control, Ride Comfort

\section{1. 緒言}

パワーエレクトロニクスの発展により，電気鉄道車両においてVVVF インバータによる誘導電動機駆動か実現 しており，鉄道車両の省エネルギ化・省メンテナンス化・高性能化に大きく貢献している .さらに , 速度センサ

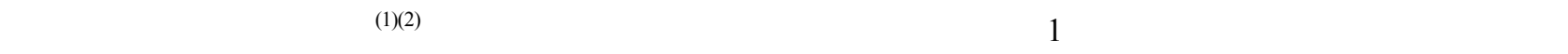
答を実現している ${ }^{(3)}$. 弚の結果, 空転・再粘着制御をはじめとする, 主電動機トルク変動を積極的に用いた制御 が可能となっている ${ }^{(4)}$.

車体の軽量化も，鉄道車両の省エネルギ化に大きく貢献している．しかしながら，車体の軽量化により車体曲 け風性が低下し，車体の弾性振動（曲げ振動）か増加する傾向にあることか指摘されている(5) . 特に，車体の弾 性振動のうち, 車体曲げの一次振動の固有振動数は 7 10Hz 程度であり, 乗客が上下振動に対して敏感な周波数 帯域と一致する . 兴のため, 高速化や快適性の要求水準向上といった理由とあわせて, 車体弾性振動の増大によ る乗り心地悪化か問題となっている . また, 近年の車両では, 台車枠の固有振動数と車体の弾性振動の固有振動 数が近接していることにより, 軌道上下狂いに起因する車体弾性振動の増大力指摘されている ${ }^{(0)}$.

車体弾性振動の増大に対し，これまでに樣々な弾性振動の低減方法か提案されている(6)(11) . しかしながら，こ れまでに提案されている振動低減方法は，いずれも車体もしくは台車への部品追加やハードウェアの改造を必要 とする、特に，電動台車は付随台車に比べて主電動機・駆動装置を有しており構造が複雑であることから，部品 追加やハードウェアの改造は困難と予測される.さらに,車体弾性振動をアクティブ制御 ${ }^{(8)(9)}$ て抑制するには, 新 たなアクチュエータが必要なだけでなく，アクチュエータを駆動するためのエネルギ源を確保する必要があると いう問題がある.

一方で, 国内の電気鉄道車両用の台車の半数程度は, 駆動用主電動機というアクチュエータを備えた電動台車 である . 国内の動力分散式電気鉄道の大半に用いられている平行カルダン駆動台車は, 主電動機が台車枠に装荷 されており，また駆動装置の反力か釣りリンクを介して台車枠で受けている．关のため，主電動機トルクによる

* 原稿受付 2010 年 11 月 8 日

*1 正員, 東洋電機製造研究センター（率236-0004 神奈川県横浜市金沢区福浦 3-8）

*2 正員, フェロー, 東京農工大学大学院

E-mail: makishima@toyodenki.co.jp 
駆動・制動時に，台車枠に力がかかることにより，台車枠のダイナミクスに大きく影響を及ぼすと考えられる． しかしながら，駆動系が台車系の前後動以外のダイナミクスに与える影響は十分に検討されてはいない(14).

主電動機トルクが台車枠のダイナミクスに影響を及ぼすことから，主電動機トルクを適切に制御することによ り台車枠振動を抑制できることが予測される . そのため, 主電動機を振動制御用アクチュエータとして用いるこ とにより，既存のハードウェアにより車体弾性振動の抑制が実現できる可能性がある. 鉄道用主電動機は, 架線 より電力供給が得られるVVVF インバータにより駆動されることから，すでにエネルギ源か確保されている．ま た，VVVF インバータは回生運転にも対応しており，振動抑制は振動エネルギを吸収する方向の仕事をすること から , 振動エネルギの回生も期待できる .

本論文ではまず,台車駆動系モデルの振動解析を行ない, 主電動機トルクと台車振動との関連を明らかにする . 振動解析の結果から，1 台の台車内の 2 台の主電動機に逆方向のトルクを重畳させることにより，台車枠に対し て上下方向の力が発生し，一次ばねのアクティブサスペンションとして動作可能なことを示す．

鉄道台車の一次ばねの制御としては, これまでに軸ダンパの可変減衰制御が提案されており，台車枠振動の抑 制により車体の曲け振動が低減されていることか報告されている(10)(13). 弚のため, 台車枠振動の抑制が可能であ れば，車体弾性振動の抑制か期待できる．乥こで本論文では，主電動機を個別に駆動する電気鉄道車両を対象と した既存の機械的ハードウェアで車体のアクティブ振動抑制可能な手法として, 主電動機トルクを用いて台車枠 振動を抑制することにより，車体弾性振動の抑制か期待できる手法を提案する．また，実台車を用いた実験によ り，主電動機トルクを用いて台車枠振動の抑制が可能なことを確認する．

\section{2. 台車・駆動系モデルと振動特性}

\section{$2 \cdot 1$ 台車·駆動系モデル}

本論文て対象とする台車モデルを, 図 1 に示す . 台車モデルは, たわみ板継手を用いた平行カルダン駆動台車

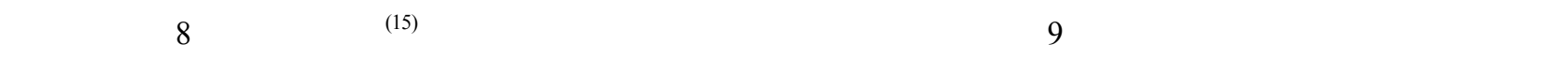
再粘着制御の検証として実績があり，実車との比較より妥当性も確忍されている ${ }^{(16)}$.

各パラメータは, 対象とする台車により相違があると思われるが, 支配的な動きや振動モ一ド形状に関しては 同樣な傾向がみられると予測される .乥こで本論文では，一例として実軸主電動機と CFRP 製のたわみ板継手(17)(18) を用いた，在来線電車相当のパラメータを用いた場合の，台車・駆動系の振動解析を行う.

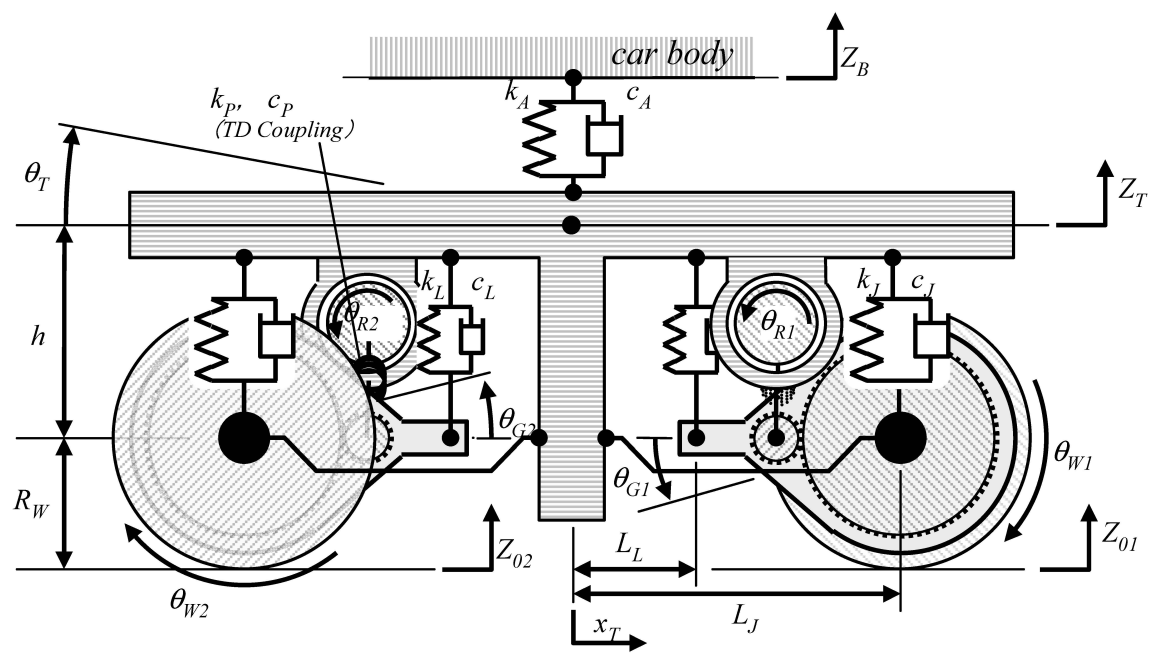

Fig. 1 Truck model with parallel cardan driving devices

台車・駆動系の運動方程式は，次の通りである．

$$
\begin{aligned}
M_{T} \ddot{Z}_{T}= & -\left\{2\left(k_{J}+k_{L}\right)+k_{A}\right\} Z_{T}-L_{J L} k_{L} \theta_{G 1}+L_{J L} k_{L} \theta_{G 2}+k_{A} Z_{B}+\left(k_{J}+k_{L}\right) Z_{01}+\left(k_{J}+k_{L}\right) Z_{02} \\
& -\left\{2\left(c_{J}+c_{L}\right)+c_{A}\right\} \dot{Z}_{T}-L_{J L} c_{L} \dot{\theta}_{G 1}+L_{J L} c_{L} \dot{\theta}_{G 2}+c_{A} \dot{Z}_{B}+\left(c_{J}+c_{L}\right) \dot{Z}_{01}+\left(c_{J}+c_{L}\right) \dot{Z}_{02}
\end{aligned}
$$




$$
\begin{aligned}
& I_{T} \ddot{\theta}_{T}=-2\left(L_{J}{ }^{2} k_{J}+L_{L}{ }^{2} k_{L}\right) \theta_{T}+L_{L} L_{J L} k_{L} \theta_{G 1}+L_{L} L_{J L} k_{L} \theta_{G 2}-\left(L_{J} k_{J}+L_{L} k_{L}\right) Z_{01}+\left(L_{J} k_{J}+L_{L} k_{L}\right) Z_{02} \\
& -2\left(L_{J}{ }^{2} c_{J}+L_{L}{ }^{2} c_{L}\right) \dot{\theta}_{T}+L_{L} L_{J L} c_{L} \dot{\theta}_{G 1}+L_{L} L_{J L} c_{L} \dot{\theta}_{G 2}-\left(L_{J} c_{J}+L_{L} c_{L}\right) \dot{Z}_{01}+\left(L_{J} c_{J}+L_{L} c_{L}\right) \dot{Z}_{02} \\
& -h\left(F_{1}+F_{2}\right)+h_{2} F_{B}+\tau_{1}+\tau_{2} \\
& I_{G} \ddot{\theta}_{G i}=-\left\{L_{j L}{ }^{2} k_{L}+\left(1+G_{R}\right)^{2} k_{p}\right\} \theta_{G i} \mp L_{J L} k_{L} Z_{T}+L_{L} L_{J L} k_{L} \theta_{T}+\left(1+G_{R}\right) k_{p} \theta_{R i}-\left(1+G_{R}\right) G_{R} k_{p} \theta_{W 1} \pm L_{J L} k_{L} Z_{0 i} \\
& -\left\{L_{j L}^{2} c_{L}+\left(1+G_{R}\right)^{2} c_{p}\right\} \dot{\theta}_{G i} \mp L_{J L} c_{L} \dot{Z}_{T}+L_{L} L_{J L} c_{L} \dot{\theta}_{T}+\left(1+G_{R}\right) c_{p} \dot{\theta}_{R i}-\left(1+G_{R}\right) G_{R} c_{p} \dot{\theta}_{W 1} \pm L_{J L} c_{L} \dot{Z}_{0 i} \\
& I_{R} \ddot{\theta}_{R i}=\tau_{i}-k_{p} \theta_{R i}+\left(1+G_{R}\right) k_{p} \theta_{G i}+G_{R} k_{p} \theta_{W i}-c_{p} \dot{\theta}_{R i}+\left(1+G_{R}\right) c_{p} \dot{\theta}_{G i}+G_{R r} c_{p} \dot{\theta}_{W i} \\
& I_{W} \ddot{\theta}_{W i}=-G_{R}{ }^{2} k_{p} \theta_{W i}-\left(1+G_{R}\right) G_{R} k_{p} \theta_{G i}+G_{R} k_{p} \theta_{R i}-G_{R}{ }^{2} c_{p} \dot{\theta}_{W i}-\left(1+G_{R}\right) G_{R} c_{p} \dot{\theta}_{G i}+G_{R} c_{p} \dot{\theta}_{R i}-R_{W} F_{i} \\
& M_{T} \ddot{X}_{T}=F_{1}+F_{2}-F_{B}
\end{aligned}
$$

なお，ここで，

$M_{T} \quad:$ 台車枠慣性質量

$I_{T} \quad$ : 台車枠ピッチンク慣性モーメント

$I_{G} \quad$ : 駆動装置慣性モーメン卜 (小歯車含む)

$I_{R} \quad:$ 電動機回転子慣性モーメン卜

$I_{W} \quad$ : 車輪慣性モーメン卜 (大歯車・車軸含む)

$L_{J}:$ 台車中心 - 車軸間水平距離

$L_{L} \quad$ : 吊りリンク - 車軸間水平距離

$L_{J} \quad$ : 台車中心 - 吊りリンク間水平距離 $\left(=L_{J}-L_{L}\right)$

$h \quad:$ 車軸 - 台車中心垂直距離

$h_{2} \quad:$ 台車中心 - けん引装置垂直距離

$R_{W}:$ 車輪径

$G_{R}:$ ギア比

$k_{A}, c_{A}:$ 空気ばねのばね定数及び咸衰係数

$k_{J}, c_{J}:$ 軸ばねのばね定数及び咸衰係数

$k_{L}, c_{L}:$ 吊りリンクのばね定数及び減衰係数

$k_{P}, c_{P}:$ たわみ板継手のねじれ岡性及び咸衰

$x_{T} \quad:$ 台車枠前後変位

$\mathrm{Z}_{T} \quad$ : 台車枠上下变位

$\theta_{T} \quad:$ 台車枠ピッチング角

$\theta_{G i}: i$ 軸の駆動装置回転角

$\theta_{R i} \quad: i$ 軸の電動機回転子回転角

$\theta_{W i}: i$ 軸の車輪回転角

$\tau_{i}: i$ 軸の電動機トルク

$W_{i}: i$ 軸の軸重

$Z_{0 i}: i$ 軸の上下軌道狂い

$Z_{B}:$ 空気ばね直上車体変位

$F_{i}: i$ 軸の接線力

$F_{B} \quad$ : けん引装置による前後力

である 
また，本論文では，接線力はすべり速度に比例すると仮定して，

$$
F_{i}=\frac{d \mu}{d v_{s}} W_{i}\left(R_{W} \dot{\theta}_{W 1}-\dot{x}_{T}+h \dot{\theta}_{T}\right)
$$

とする

\section{$2 \cdot 2$ 周波数応答特性}

台車・駆動系の振動特性を把握するために, 図 1 のモデルの上下軌道狂い及び主電動機のトルク入力時の, 台 車枠振動の周波数応答特性を把握する.台車内の 2 軸に対して, 同位相の上下軌道狂いに対する台車枠上下変位 の周波数応答を図 2 (a) に，逆位相の上下軌道狂いに対する台車枠ピッチ角の周波数応答を図 2 (b) に示す.また， 2 台の電動機の同位相卜ルクに対する台車枠ピッチ角の周波数応答を図 2 (c) に，逆位相卜ルクに対する台車枠上 下変位の周波数応答を図 2 (d) に示す .なお , 逆位相の入力は , 図 2 における上下軌道狂い $Z_{01}$ もしくは主電動機 $\theta_{R 1}$ が正となる方向を基準に，周波数応答の位相を表示している .
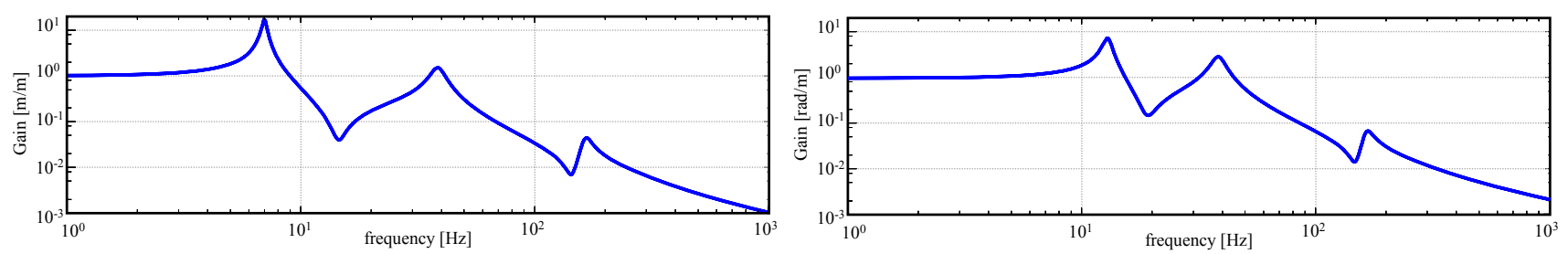

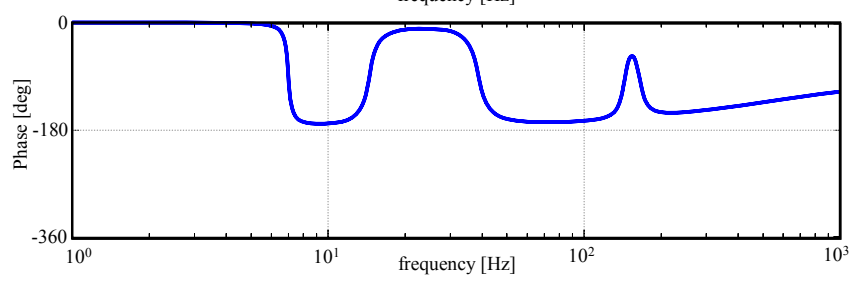

(a) Frequency response of truck frame vertical displacement with respect to in-phase vertical track irregularity
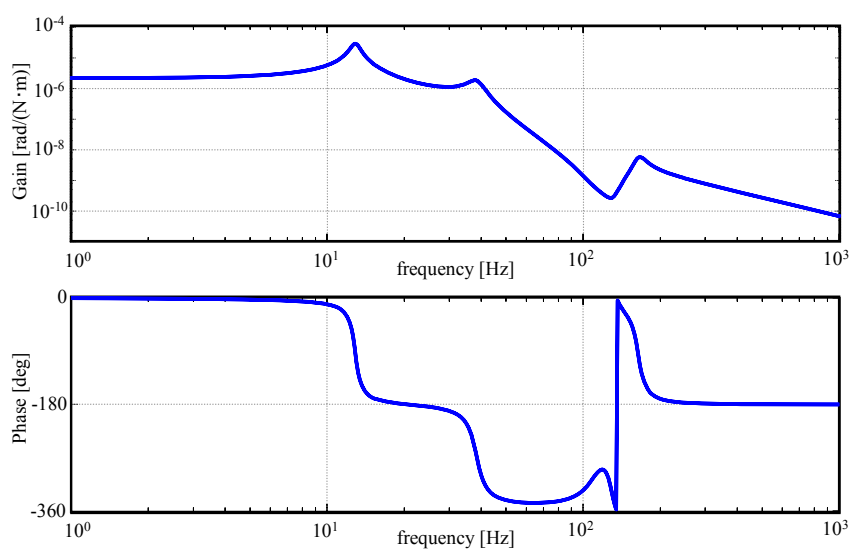

(c) Frequency response of truck frame pitching angle with respect to in-phase motor torque

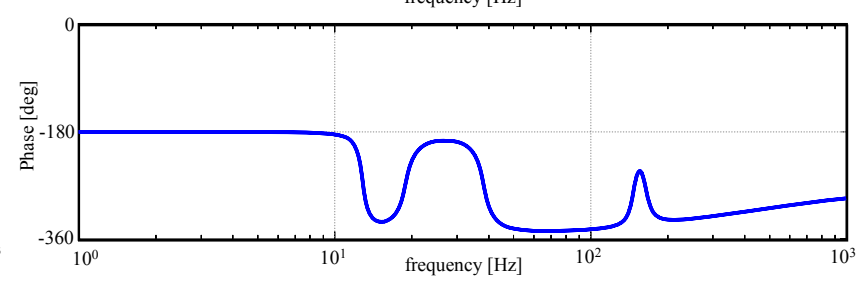

(b) Frequency response of truck frame pitching angle with respect to reverse-phase vertical track irregularity
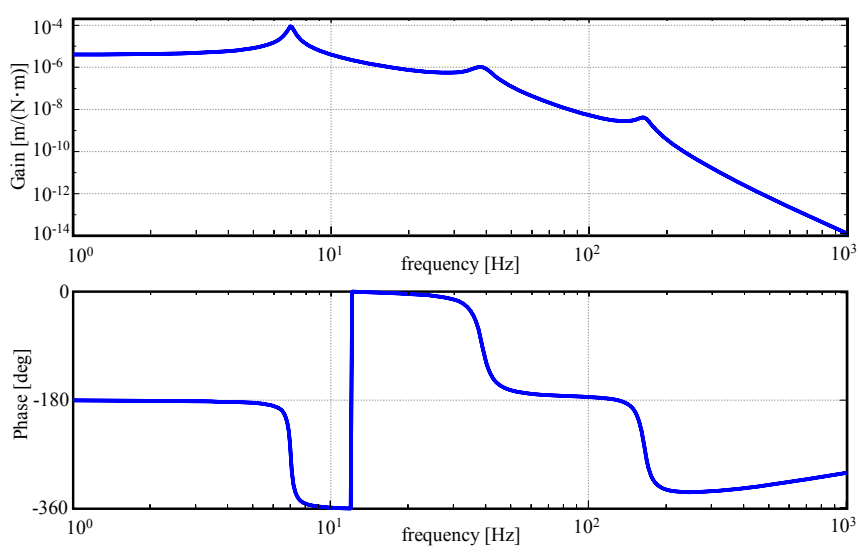

(d) Frequency response of truck frame vertical displacement with respect to reverse-phase motor torque

Fig. 2 Frequency responses of truck frame

台車枠の上下振動とピッチング振動のうち，いずれの条件であっても一方のみ加振される . 加振されないもの は伝達関数が零となるため, 図 2 では加振されるもののみ周波数応答を示している . 同位相の軌道狂いと逆位相 
の主電動機トルクでは, 台車枠の上下振動のみが加振され，逆位相の軌道狂いと同位相の主電動機トルクでは， 台車枠のピッチング振動のみが加振される .

この結果から，逆位相の主電動機トルクにより台車枠上下振動は可制御であるといえる．弚のため，車体振動 の主な加振源である台車枠の上下振動に対して , 2 台の主電動機に逆位相でトルクを加えることによって, 台車 枠の上下振動の抑制が可能であることが予測される .

\section{$2 \cdot 3$ 振動モード 解析}

図 2 の周波数応答特性から, 台車・駆動系モデルでは複数の共振ピークが見られた . この共振ピークの振動状 態を把握するために，振動モード解析を行う.

図 3 は , 減衰要素を無視した台車・駆動モデルの振動モ一ド解析結果である. 駆動・台車系モデルは台車枠上 下運動と連成する前後線対称形状のモードと，台車枠ピッチング運動と連成する前後点対称形状のモードに分離 される . TV モード・RV モード・GV モードは前後線対称形状のモードであり, 図 2 の (a) 及び (d) の共振ピー クと対応している -一方で, TP モード・RP モード・GP モードは前後点対称形状のモードであり, 図 2 の (b) 及 び (c) の共振ピークと対応している .

TV モード及びTP モードは, 台車枠振動を主体とするモードである .この2つのモードは, 吊りリンク振動や たわみ板継手のねじれ振動といった，駆動系のダイナミクスの影響は無視できるモードであり，台車枠振動に付 随して駆動系が振動している状態である．TV モードは, 車体振動の主な加振源であり, 特に車体曲げ一次の固 有振動数と周波数帯域が一致していることから，乗り心地に大きな影響を及ぼす．

一方で, RV モードと RP モードは, 吊りリンクの振動やたわみ板継手のねじれ振動が発生しており，駆動系と 台車枠振動が連成しているモードといえる . また, GV モードと GP モードは, 駆動装置の回転運動が主体で台車 枠振動との連成は少ないモードといえる．

$\mathrm{TV}$ モード・TP モード及び RV モードと RP モードは, 主電動機が台車枠振動と連成している . そのため, こ れらのモードは主電動機からみて可制御・可観測であり，この結果からも主電動機トルクにより制御可能なモー ドといえる .

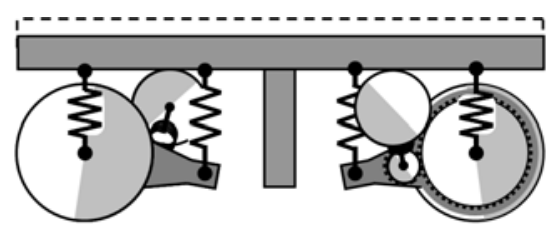

TV-Mode (7.2 Hz)

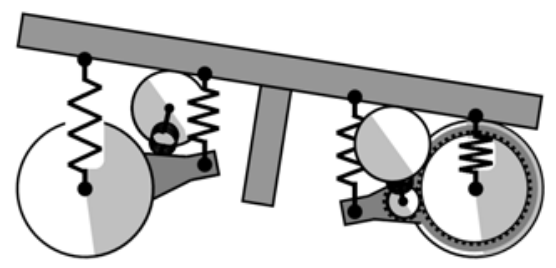

TP-Mode (13.3Hz)

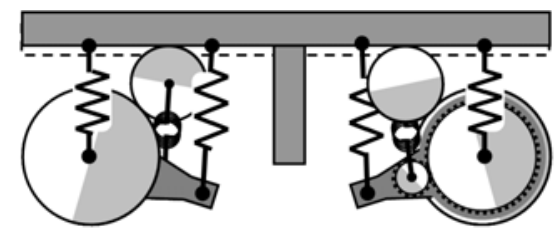

RV-Mode $(45.7 \mathrm{~Hz})$

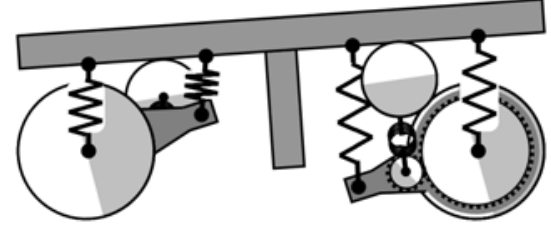

RP-Mode $(45.2 \mathrm{~Hz})$

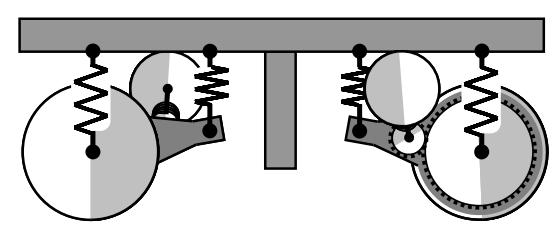

GV-Mode (166.7Hz)

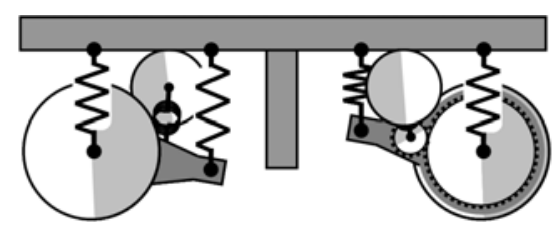

GP-Mode $(166.7 \mathrm{~Hz})$

Fig. 3 Mode shapes of truck with parallel cardan driving devices

\section{3. 振動制御の原理と制御手法}

\section{3・ 1 主電動機トルクによる振動制御の原理}

周波数応答解析及び振動モ一ド解析の結果, 主電動機トルクにより台車枠上下振動が可制御でることが示唆さ れた．弚こで，主電動機による台車枠振動の抑制を検討するにあたり，弚のメカニズムを考察する．

主電動機にトルクが発生すると，継手を介して駆動装置の小歯車が回転し，車軸に結合されている大歯車に力 
が伝達する . 小歯車は , 大歯車周りの遊星歯車運動として動作する . 产のため , 小歯車から大歯車に力が伝達す る際に , 小歯車の公転運動のモーメントを発生する．この公転運動は，駆動装置と台車枠を結ぶ吊りリンクによ って拘束される.乥のため, 小歯車から大歯車に力が伝達する際の反力が, 吊りリンク経由で台車枠へと伝わる.

すなわち, 車輪の回転が無視できれば，主電動機と駆動装置は軸ばねに並列なアクチュエータとして振舞い， 等価的に一次ばねのアクティブサスペンションとみなすことができる .2 台の主電動機に同一方向のトルクをか けると, 台車枠にピッチング方向のモーメントが発生し, 逆方向のトルクをかけると, 台車枠に上下方向の力が 発生する .

\section{$3 \cdot 2$ 制御手法}

主電動機トルクによる振動制御は，等価的に一次ばねの上下アクティブサスペンションとみなすことができる . 鉄道車両の一次ばね制御による上下振動制御手法としては，これまでに軸ダンパの可変減衰制御か提案されてい $ろ^{(10)}$.

軸ダンパの可変減衰制御手法では, 台車振動抑制による加振力抑制を主眼とした台車枠スカイフック制御と, 車体の曲げ一次振動モードのモデルを用いた LQG 制御が提案されている . 後者は , 車体の振動モデルを用いて いるため, 車体の曲げ振動を集中的に低減することが可能であり, 台車枠固有振動数と車体曲げ振動の固有振動 数か䚾離した条件であっても，高い制御効果が得られることか報告されている ${ }^{(11)}$. 一方で, 車体の一次曲け固有 振動数以外の弾性振動がある条件においては, LQG 制御に比べスカイフック制御の方が, 幅広い周波数帯域での 制御効果が得られていると報告されている ${ }^{(12)(13)}$.このことから，台車枠スカイフック制御は想定外の車体弾性振 動であっても，台車枠上下振動に起因する車体振動成分に対しては制御効果が期待できる .

近年の鉄道車体は，車体の弾性振動形状が複雑化しており，単純なはりの一次曲げ振動として扱えないものが 多いことか指摘されている(19)(20). 特に, 新幹線車両に比べて在来線車両は開口部が多いため, 振動モード形状が 複雑な傾向となることか報告されている( ${ }^{(5)}$.このことから , 近年の在来線車両のような複雑な弾性振動モ一ドを 有する車体に対しては，車体モデルを用いた制御則の適用は困難であると予測される．乥の一方で，台車枠振動 による加振を低減するという観点による車体振動制御の有効性は, 高いと考えられる .

乥こで本論文では, 台車枠の上下振動加速度の低減を目的とする手法として, 台車枠スカイフック制御をもと に制御系を検討する。

制御系の構成を図 4 に示す . 図 4 におけるモータ制御器はトルク指令が入力され , 接続された電動機はトルク 指令と一致するトルクを出力するものとする . 台車枠上下振動の低減効果を把握するために , 図 2 (a) の同位相 の上下軌道狂いに対する台車枠上下振動の周波数応答に，制御を加えた場合の周波数応答を重ねたものを図 5 に 示し制御特性の検証を行う.

2 台の主電動機の逆位相のトルクに比例した上下力が台車枠にかかるとすると, 台車枠上下振動加速度を積分 することにより得られた上下振動速度に , ゲイン $K_{P T}$ を乗じたものを 2 台の主電動機のトルク指令に逆位相で重 畳することにより，台車枠スカイフック制御を実現できると想定される . 図 5 (a) の青線は, 台車枠上下速度に 比例したトルクを,2 台の主電動機に加えた際の周波数応答である . 図 5 (a) の青線より, 車体曲げ一次振動の加 振源となる TV モード相当 (7Hz 程度) の共振ピークを大幅に低減しており，台車枠スカイフック制御の効果が 確認できる . 弚の一方で, $\mathrm{RV}$ モード相当の $40 \mathrm{~Hz}$ 程度の共振ピークを増大させる傾向がある . これは, 台車枠ス カイフック制御に駆動系のダイナミクスを考慮していないため, 駆動系ダイナミクスの影響を受ける周波数帯域 になると, 電動機トルクと台車枠上下力の位相関係か変動し, 台車枠スカイフック制御の前提が崩れるためであ る

$\mathrm{RV}$ モード相当の周波数帯域は, 空気ばねによる減衰の大きく，乗客も加速度を感じにくい周波数帯域である ことから，乗り心地悪への影響は少ないといえる．しかしながら，RV モードは駆動系が大きく共振した状態で あり，駆動機械系への負担や騒音の観点から望ましくない．

ここで, 駆動系ダイナミクスを大きく受ける図 3 の RV モードに注目すると，2 台の主電動機が逆位相で大き 〈振動していることがわかる . 弚のため, 2 台の主電動機の回転速度差をフィードバックすることにより，RV モ 一ドを拘束できると考えられる. 弚こで, 2 台の主電動機の回転速度差にゲイン $K_{P R}$ を乗じたものを，重畳卜ル クに加算する. 弚の結果, 図 5 (a) の赤線が示すように , $40 \mathrm{~Hz}$ 程度のピークを抑制しながら，7Hz 程度のピーク 


\section{を大きく抑制できる .}

なお, 車輪の慣性モーメントが十分に高いため, 振動抑制の対象とする 7〜 $10 \mathrm{~Hz}$ 程度の周波数帯域では, 車輪 回転速度変動の影響は僅かである . 弚のため，振動抑制制御による前後運動や粘着特性への影響は無視できると いえる .

図 5 (b) は,提案手法と軸ダンパを装備した場合および,軸ダンパを装備した状態て提案手法を行った場合の， 周波数応答の比較である . 図 5 (b) より, 軸ダンパを装備した状態であっても，提案手法は有効であることがわ

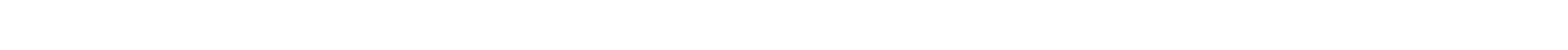
枠の上下振動の抑制か実現されていることがわかる .

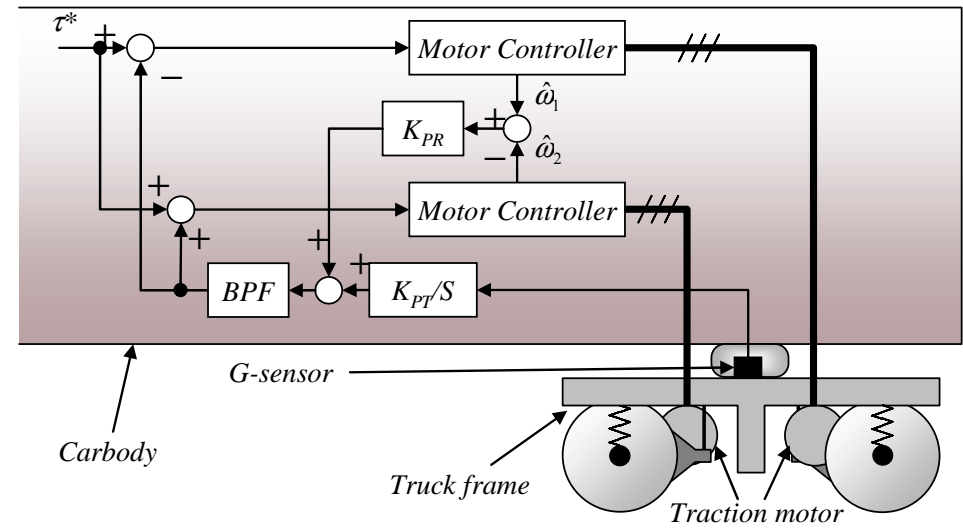

Fig. 4 Block diagram of the controller
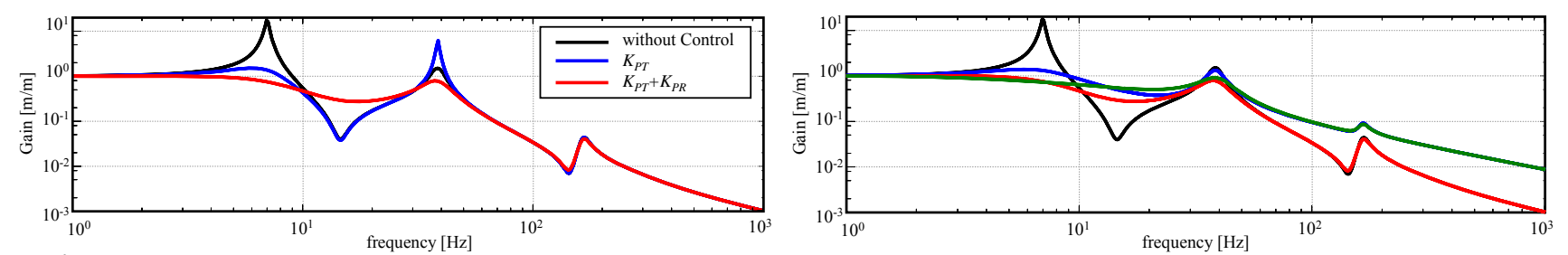

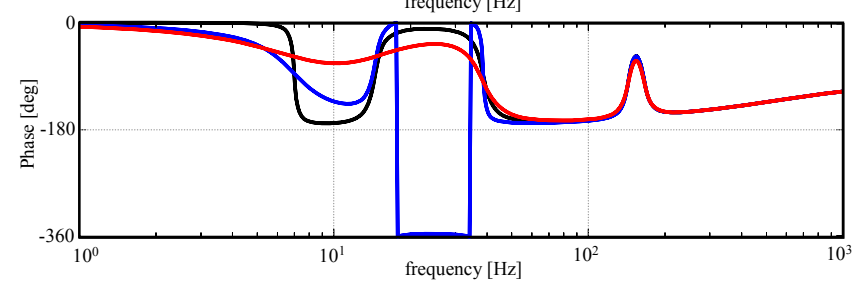

(a) Effects of controllers

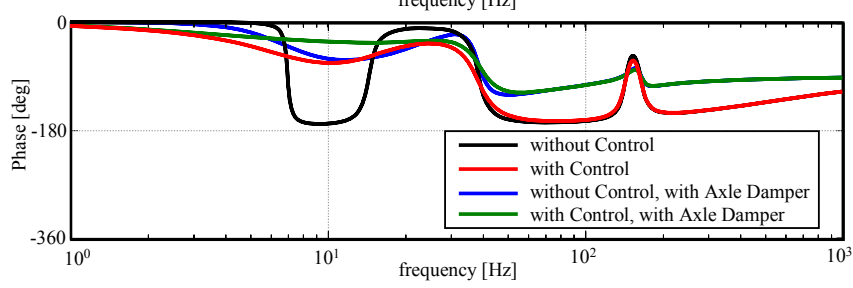

(b) Effects of controller and axle damper

Fig. 5 Frequency responses of truck frame

\section{1 実験構成}

\section{4. 台車試験装置による実験検証}

主電動機トルクによる台車振動の抑制の検証のために，台車試験装置を用いて実台車による実験を行うなお，

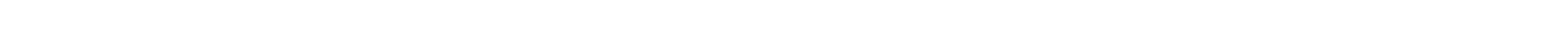
と予測されるため，本論文では台車単体での試験とし，台車枠振動の抑制の可否により評価する．

図 6 に，実験に用いる台車試験装置および台車の写真を，図 7 に構成図を示す . 本台車は, スイングハンガ・ 摇れ枕もり等を用いた構成であり, 近年の台車に比べ褶動部が多くいため共振ピークが見えにくい傾向が予測さ れる．また，本台車の駆動系の構成は，中空軸の主電動機回転子を有し反歯車側と歯車側のたわみ板の間をねじ れ軸を用いて伝達する, 中空軸平行カルダン方式である(21). 中空軸平行カルダン駆動台車の力学モデルは, 図 1 の構成と同等であるものの, 近年の実軸主電動機によるたわみ板継手方式に比へて継手のねじれ岡性か溺い傾向 
があり，継手のねじれ振動か生じやすいとの指摘がある ${ }^{(22)}$.これらの理由から，本台車は近年の台車に比へ提案 手法の適用の難易度が高い台車であるといえる．

台車は軌条輪の上に乗った状態であり 動電型加振機により台車枠を直接加振する 加振機と台車枠の間には， ロードセルを設けて加振力を測定する . また , 軌条輪に凹凸を設けた状態で, 主電動機から軌条輪回転させるこ とにより，実際に軌道上下外乱のある状態を模擬する．

主電動機は, 定格出力 $120 \mathrm{~kW}$ の誘導電動機が装荷されている.主電動機の駆動は, 東洋電機製造製の一般産業 用インバータVF66B(7.5kW)を用い,内蔵 PLC 機能の Control Block Editor を用いて振動抑制制御の構築を行う. 本装置の台車枠は, 台車上の荷重枠と岡結合された状態であるため, 荷重枠の中心部の加速度を台車枠加速度 とみなし , フィードバック制御およひ評価に用いる。

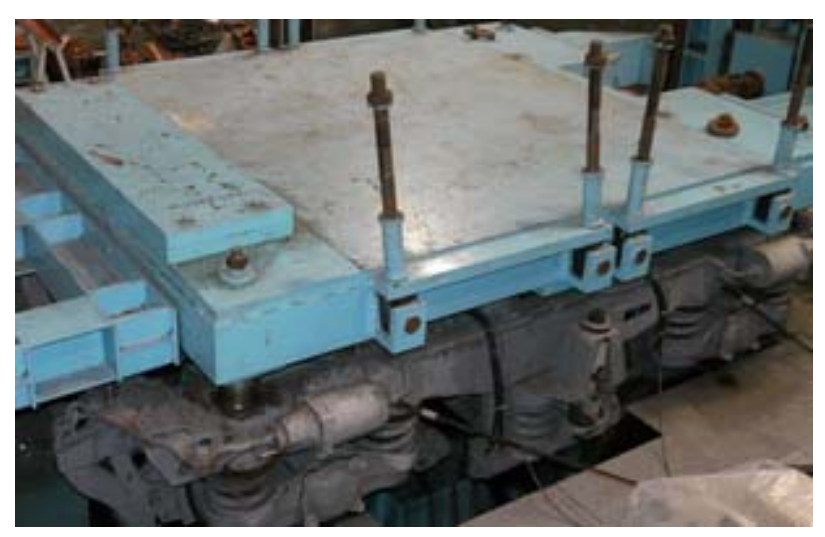

Fig. 6 Bogie testing machine

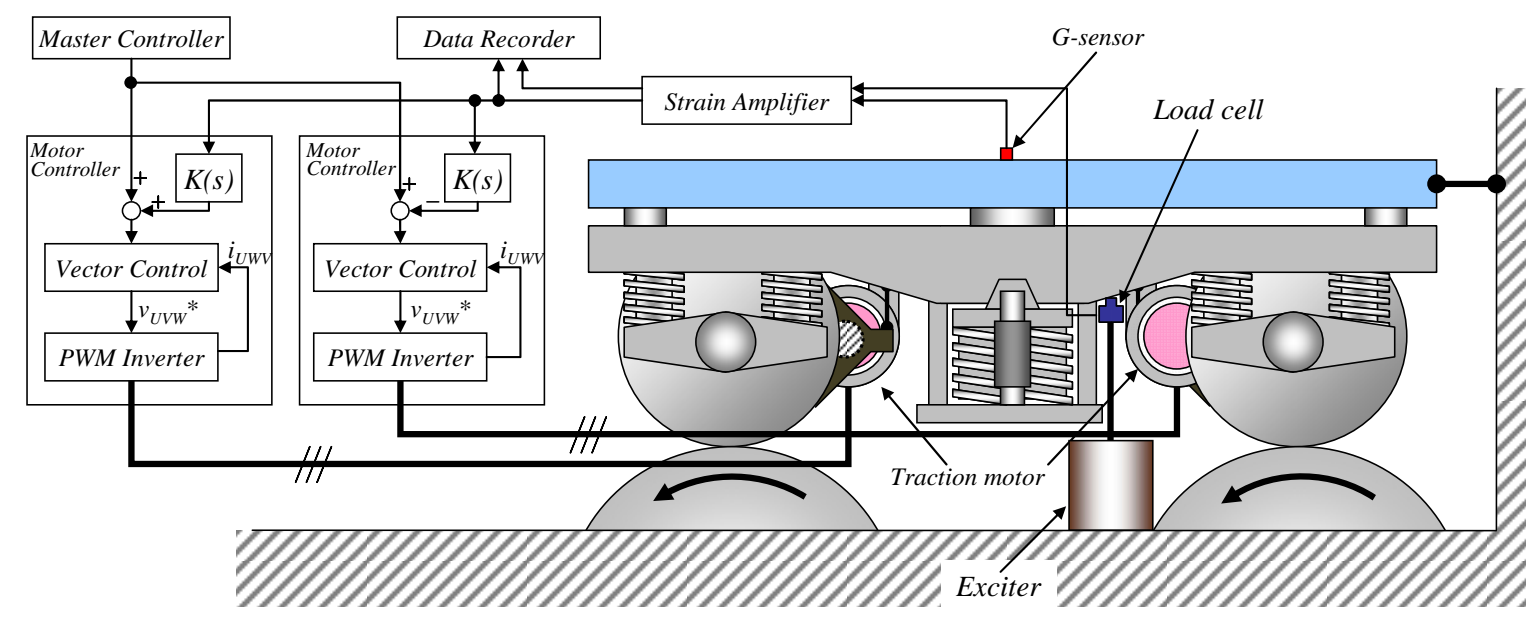

Fig. 7 Experimental setup

\section{4· 2 台車振動特性}

図 8 (a) に, 台車枠を加振機で3〜20Hz までスイープ加振した際の, 台車枠上下振動の周波数応答を示す . 図 8 (a) における $10.5 \mathrm{~Hz}$ 付近の振動ピークが, 台車枠の上下振動の共振ピークである . なお , $8 \mathrm{~Hz}$ 付近にもピーク がみられるが , これは加振点が台車の前後中心位置からずれているため, ピッチング系のモードを励起している ためである .

2 台の主電動機に逆位相の正弦波トルクをかけ, $1 \mathrm{~Hz}$ から $20 \mathrm{~Hz}$ までスイープさせた際の, 主電動機トルクに対 する台車枠上下加速度の周波数応答を図 8 (b) に示す.図 8 (b) より, 主電動機に逆位相で卜ルクを掛けた際に台 
車枠の上下振動が発生している .このことから，主電動機に逆位相でトルクを発生させることにより台車枠上下 力の発生か確認され, 主電動機トルクにより台車枠上下振動制御が可能なことが示唆された .

図 8 (b) において，台車枠上下振動の共振ピークである $10.5 \mathrm{~Hz}$ より低い周波数である，3Hz 付近および $7 \mathrm{~Hz}$ 付 近に大きなピークがみられ, 位相も変化している.これは, 主電動機から台車枠までの力の伝達経路に, 台車枠 固有振動数より低い周波数の固有振動数が存在していることを意味している.すなわち，中空軸平行カルダン駆 動のたわみ板継手およびねじれ軸のねじれ振動が生じていると推察でき，シミュレーションで用いた実軸主電動 機のたわみ板継手方式の台車とは大きく異なる台車であるといえる .
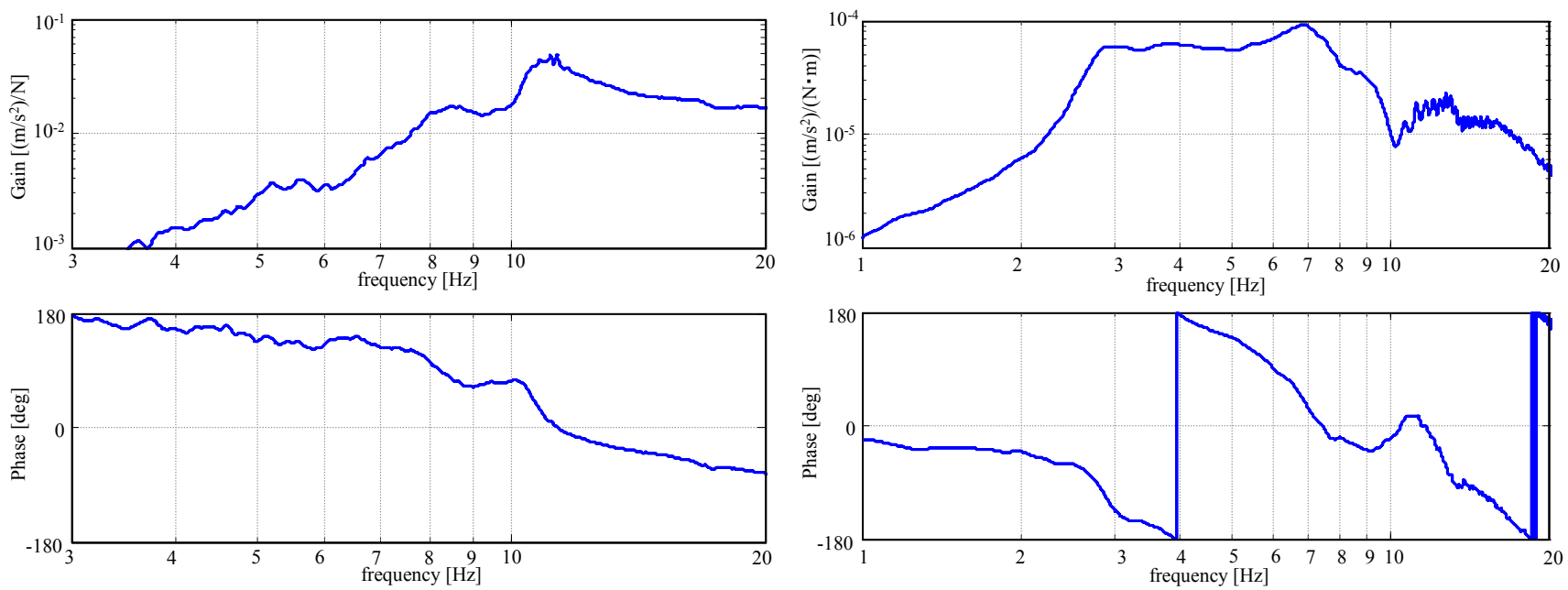

(a) Frequency response of truck frame vertical displacement with respect to excite force

(b) Frequency response of truck frame vertical displacement with respect to reverse-phase motor torque

Fig. 8 Frequency responses of truck frame

\section{3 制御方法}

3 章で提案した制御手法は, 振動抑制を行う周波数帯域において, 逆位相の主電動機トルクと台車枠の上下力 が比例関係にあるという前提で成立する.すなわち，本台車のように振動抑制を実施する周波数帯域より低い周 波数に駆動系の固有振動数が存在する場合, 主電動機トルクと台車枠に働く上下力の位相関係が崩れて台車枠ス カイフック制御が成立しない。

駆動系の固有振動数が台車枠の上下振動の固有振動数より低い場合，位相遅れを考慮した制御系の構築が必要 となる . 位相遅れの考慮した制御系としては, 位相遅れをモデル化したモデルベース制御を用いる手法がある . 一方で, モデルベース制御はモデル化誤差やパラメータ変動時のロバスト性確保が問題となる．特に台車・駆動 系は, 同定困難な高次の駆動系振動や台車枠の弾性振動が存在し非線形要素も多いため, これらに対するロバス 卜性を確保した制御手法か望まれる。

そこで, 本実験では, 主電動機トルクから台車枠上下振動までの伝達関数モデルに基づく, $\mathrm{H}_{\infty}$ 制御を適用する。 制御設計モデルは, 図 8 (b) に基づき, 駆動系固有振動数と予測される $10 \mathrm{~Hz}$ 以下の 2 つの共振ピークと, 台車枠 上下振動の固有振動数である $11.5 \mathrm{~Hz}$ 付近のピークをモデル化し, 弚れより高い周波数帯域は乗法的誤差とみなし てロバスト安定性を確保することにより悪影響を防ぐことにする．

制御系設計の一般化プラントを図 9 に, 周波数重みを図 10 に示す.重み $\mathrm{W}_{1}$ は振動抑制のためのものであり， 台車枠の上下振動の固有振動数付近である $12 \mathrm{~Hz}$ 程度の重みが大きくなるようにする.重み $\mathrm{W}_{2}$ はモデル化してい ない駆動系の高次モードや台車枠の弾性振動といった高次モードに対するロバスト安定性を確保するものである． また , 低周波の振動トルクによりトルク変動振幅力増大することを防ぐために , 重み $\mathrm{W}_{3}$ を導入する . 


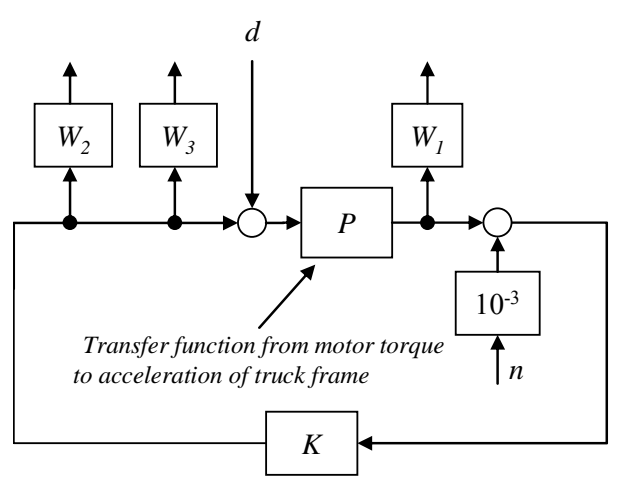

Fig. 9 Generalized plant of $\mathrm{H}_{\infty}$ Controller

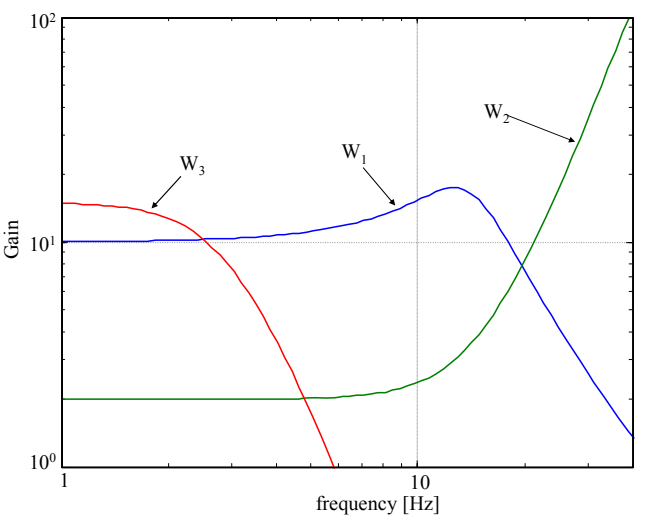

Fig. 10 Frequency weights

\section{4- 4 実験結果}

加振機によるスイープ加振時の制御の有無による , 加振力から台車枠上下加速度までの周波数応答を，図 11 に示す . 図 11 より，制御により $11.5 \mathrm{~Hz}$ 程度の振動ピークが低減されていることか確認できる.

主電動機の回転速度を $60 \mathrm{~min}^{-1}$ で運転し 軌条輪の凹凸により加振された状態での台車振動加速度のパワースペ クトル密度を図 12 に示す.なお，図 12 の凡例中に , 振動加速度の RMS 值を記載している．

図 12 より振動抑制制御を行うことにより 6 20Hzの周波数帯域て振動加速度のスペクトルが低下しており， 特に $6 \mathrm{~Hz}$ 付近と $12 \mathrm{~Hz}$ 付近にみられる振動ピークが大きく低減できていることがわかる .また振動加速度の RMS 值でみても，2 割以上の加速度低減効果か確認された 。

図 12 て振動低減効果がみられた周波数帯域は,乗客が上下方向に敏感な周波数帯域と一致しており，また乗り 心地の問題となる車体弾性振動の固有振動数が含まれていることから, 乗り心地改善に貢献できると予測できる 結果といえる .

なお，図 11 の加振機による加振時には制御時に $15 \mathrm{~Hz}$ 付近の振動が悪化する傾向があつたが, 図 12 の軌条輪 を回転させた状態では，この周波数帯域での振動抑制か確認できた . これは，加振機による加振では加振力の制 約上加速度振幅が小さく，制御の分解能か不足することにより非線形性が生じ , 低い周波数領域で高周波振動を 励起したためと推測される .

今回用いた台車は, 近年の台車に比べて提案手法の適用か灘しいものであったが, 台車枠加速度フィードバッ クに基づき 2 台の主電動機に逆位相のトルクを重畳することにより，台車枠振動の抑制が可能なことが原理的に 示された . 近年の実軸主電動機によるたわみ板継手や歯車形継手を用いた台車の場合，継手のねじれ岡性が高い ため，より容易に高い振動抑制効果か期待される.
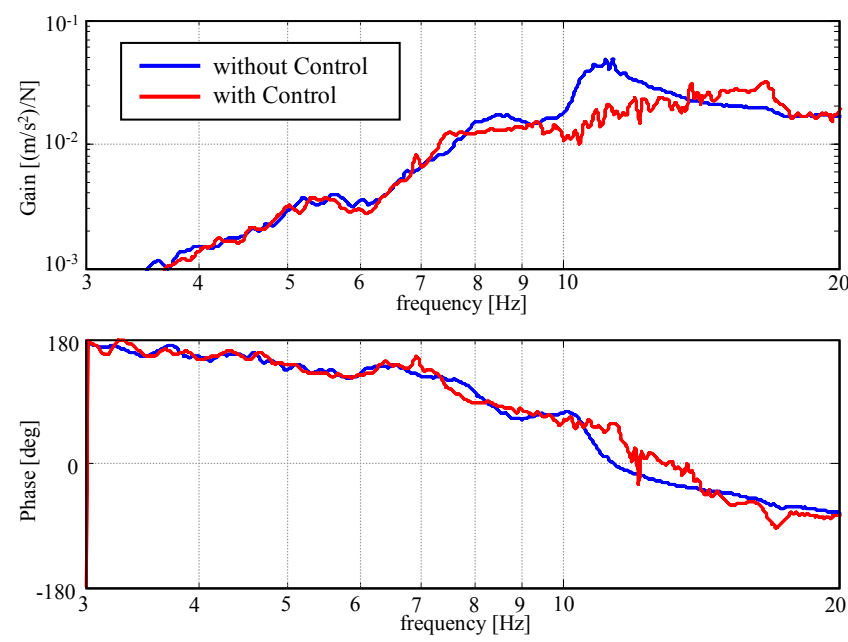

Fig. 11 Frequency response of truck frame vertical displacement with respect to excite force

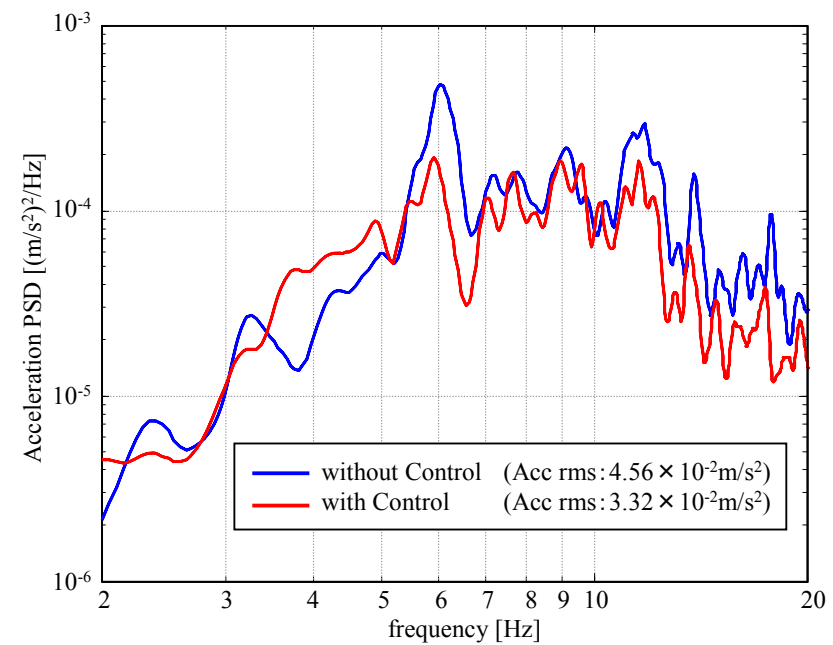

Fig. 12 Acceleration PSD of truck frame. 


\section{5. 結 語}

本論文では, 主電動機を個別に駆動する電気鉄道車両を対象とした, 既存のハードウェアによる鉄道車体のア クティブ振動抑制手法として , 平行カルダン駆動台車の主電動機トルクにより，車体振動の抑制を行う手法の検 討を行った。

車体振動抑制手法を検討するにあたり，平行カルダン駆動台車の駆動・台車系の周波数応答解析及ひ振動モ一 ド解析により, 主電動機トルクと台車枠上下振動の関係を明らかにした . 弚の結果，台車内の 2 台の主電動機に 逆位相のトルクを重畳させることにより，台車枠に上下力の発生が可能であることが判明した .

そこで，２台の主電動機に逆位相のトルクを重畳することにより台車振動を抑制し，間接的に車体振動を抑え

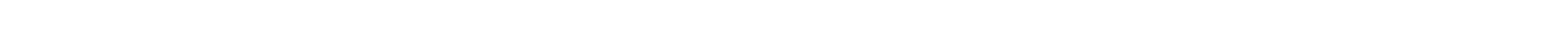
もとに, 駆動系のダイナミクスの安定化を加えた手法である. 本手法は , 機械的なハードウェアの追加や改造な しで, 車体のアクティブ振動抑制か実現できるという特徵がある .

最後に，台車試験装置を用いた試験により，提案手法の検証を行った . 実験で用いた台車は，近年の駆動台車 と異なる中空軸平行カルダン方式であり，継手のねじれ岡性が低いことから提案した制御の適用は不可能であっ たが, 駆動系の特性を考慮した $\mathrm{H}_{\infty}$ 制御の適用により振動抑制か確認された .この結果から, 台車枠加速度のフ イードバックによる主電動機トルク制御により，台車枠振動の抑制が可能なことが原理的に実証された．また駆 動系の固有振動数が台車枠上下振動の固有振動数より低く制御が困難な台車であっても，振動抑制が可能である ことか確認された . 近年の実軸主電動機によるたわみ板継手もしくは歯車形継手を用いた電動台車では，継手の ねじれ岡性が高いため，より容易に高い振動抑制効果が得られることか期待できる．

なお，電気鉄道車両においては，複数の主電動機を並列接続して制御する場合も多くみられる．本論文では， 主電動機を個別に駆動する場合を前提としているが, 前後対象形状の振動モードに対しては, 前後台車間での主 電動機を並列接続して車体振動抑制が可能なことを確認している(23).

また，本手法は電動台車に対する手法であることから，付随車への適用は不可能である．しかしながら，電動 台車は付随台車にくらべて構成が腹杂雑であることを考えると，付随車に対しては他の振動抑制手法を用い，電動 車に対しては今回提案した手法を適用するという構成は，有効であると考える．

付 録

本論文の 2 章および 3 章で用いた , パラメータの一覧を表 1 に示す .

Table 1 Parameters of truck with parallel cardan drives

\begin{tabular}{c|l||c|l||c|c}
\hline \hline parameter & \multicolumn{1}{|c|}{ value } & parameter & \multicolumn{1}{|c||}{ value } & parameter & \multicolumn{1}{c}{ value } \\
\hline$M_{T}$ & $2.29 \times 10^{3}[\mathrm{~kg}]$ & $h$ & $0.120[\mathrm{~m}]$ & $\begin{array}{c}C_{J} \text { (without axle } \\
\text { damper) } \\
C_{J} \text { (with axle } \\
\text { damper) }\end{array}$ & $5.20 \times 10^{3}[\mathrm{~N} /(\mathrm{m} / \mathrm{s})]$ \\
$I_{T}$ & $7.62 \times 10^{2}\left[\mathrm{~kg} \square \mathrm{m}^{2}\right]$ & $h_{2}$ & $0.145[\mathrm{~m}]$ & $k_{L}$ & $1.75 \times 10^{4}[\mathrm{~N} /(\mathrm{m} / \mathrm{s})]$ \\
$I_{G}$ & $16\left[\mathrm{~kg} \square \mathrm{m}^{2}\right]$ & $R_{W}[\mathrm{~N} / \mathrm{m}]$ \\
$I_{R}$ & $1.9\left[\mathrm{~kg} \square \mathrm{m}^{2}\right]$ & $0.43[\mathrm{~m}]$ & $c_{L}$ & $4.00 \times 10^{3}[\mathrm{~N} /(\mathrm{m} / \mathrm{s})]$ \\
$I_{W}$ & $72.4\left[\mathrm{~kg} \square \mathrm{m}^{2}\right]$ & $G_{R}$ & 4.89 & $k_{P}$ & $2.77 \times 10^{5}[\mathrm{~N} / \mathrm{m}]$ \\
$L_{J}$ & $1.05[\mathrm{~m}]$ & $k_{A}$ & $1.08 \times 10^{6}[\mathrm{~N} / \mathrm{m}]$ & $C_{P}$ & $2.54[\mathrm{~N} /(\mathrm{m} / \mathrm{s})]$ \\
$L_{L}$ & $0.5037[\mathrm{~m}]$ & $c_{A}$ & $3.00 \times 10^{5}[\mathrm{~N} /(\mathrm{m} / \mathrm{s})]$ & $W_{i}$ & $6.25 \times 10^{4}[\mathrm{~N}]$ \\
\hline
\end{tabular}

文献

（1）上園恵一，高木正志，佐野孝 “ 車両用速度センサレスベクトル制御”，東洋電機技報，No. 104 (1990), pp1-7

（2）佐野孝＂“交通用センサレス速度制御システム”，東洋電機技報，No. 109 (2003), pp.14-23

（3）牧島信吾，上園恵一，永井正夫 “電圧飽和状態における電動機制御応答特性の検証及び考察”，電気学会論文誌, Vol. 130-D, No .5 (2010), pp. 663-670 
（4）門脇悟志, 畑正, 廣瀬寛, 大石潔, 飯田哲史, 高木正志, 佐野孝, 保川忍 ““速度センサレスベクトル制御・外乱 オブザーバによる空転再粘着制御の実車両への適用と光の評価—205 系 5000 番台電車における実例—”，電気学会 論文誌，Vol. 124-D, No. 9 (2004), pp. 909-916

（5）瀧上唯夫，富岡隆弘，“最近の軽量車両の固有振動モード特性” , 鉄道総研報告 , Vol. 16, No. 5 (2002), pp.23-28

(6) 佐々木浩一 “新幹線高速走行時の上下振動乗り心地の改善 (高速鉄道車両の振動系設計手法)” , JR EAST Technical Review, No. 6 (2004), pp. 67-72

（7）鈴木康文 “"鉄道車両の快適性向上”，日本機械学会第 18 回交通・物流部門大会講演論文集 (2009), pp.23-29

（8）永井正夫，沢田康宏＂“柔構造弾性車体のアクティブ支持制御”，日本機械学会論文集 C 編，Vol. 53, No. 492 (1987), pp. 1750-1757

（9）遠竹隆行，相羽哲郎，鎌田崇義，永井正夫 “ スマート構造技術による柔軟構造車体の振動制御に関する研究”，日 本機械学会第 13 回交通・物流部門大会講演論文集 (2004), pp. 167-170

(10) 菅原能生, 瀧上唯夫, 三平満司，“可変減衰軸ダンパを用いた鉄道車両の上下振動低減”, 日本機械学会論文集 C 編, Vol. 72, No. 721 (2006), pp.2770-2778

（11）菅原能生，瀧上唯夫，小金井玲子 “鉄道車両の 1 次ばね系の減衰制御による上下振動低減”，日本機械学会論文集 C 編，Vol. 75, No. 753 (2009), pp. 1304-1311

（12）瀧上唯夫，菅原能生，小金井玲子，“隣接車両の運動が車体曲げ振動に与える影響について”，日本機械学会第 18 回交通・物流部門大会講演論文集 (2009), pp.141-144

(13) 菅原能生, 小島崇, 瀧上唯夫, 富岡隆弘, 相田健一郎, 朝長篤司，八野英美““ 1 次ばね系の減衰制御による車体 上下弾性振動の低減(車端にダンパを有する車両の場合)”，第 16 回鉄道技術連合シンポジウム講演論文集 (2009), pp. $151-154$

(14) 日本機械学会編, 鉄道車両のダイナミクス, (1994), p129, 電気車研究会

(15）牧島信吾 , 保川忍, 永井正夫 “ 平行カルダン駆動台車における主電動機トルクによるダイナミクス制御の基礎検 討”，日本機械学会第 18 回交通・物流部門大会講演論文集 (2009), pp. 137-140

（16）清水陽介，門脇悟志，大石潔，畑正，佐野孝，保川忍，“電気車の外乱才ブザーバを用いた空転滑走再粘着制御の 評価と考察”，電気学会論文誌，Vol. 127-D, No. 8 (2007), pp. 918-925

（17）松山晋作，大場宏明，赤壁毅彦，小野寛 “' CFPR 製たわみ板の耐久性評価”，東洋電機技報 , No.78 (1990), pp. 38-45

（18）大島哲二，水沢正幸，矢吹敬＂“ TD 継手を用いた駆動装置の振動解析”，東洋電機技報，No.61 (1985), pp. 2-11

（19）相田健一郎,富岡隆弘, 瀧上唯夫“, 車体構造の違いによる在来線車両の車体固有振動モード特性の比較”,第 14 回 鉄道技術連合シンポジウム講演論文集 (2007), pp. 143-146

(20) 相田健一郎, 富岡隆弘, 瀧上唯夫, 谷口宏次, 今岡憲彦; “樣々な鉄道車両の車体固有振動モード特性の比較”, 第 17 回鉄道技術連合シンポジウム講演論文集 (2010), pp. 325-328

（21）原田良介編 “"主電動機およひ駆動装置”，東洋電機技報第34 号 (1978), pp. 3-11

(22) 弘津哲二, 河西省司, 高井英夫 “電車平行カルダン駆動装置の空転時自励振動”, 日本機械学会論文集 C 編, Vol. 52, No. 483 (1986), pp2843-2849

(23) 牧島信吾, 永井正夫 “ 電気鉄道車両の主電動機を用いた車体振動抑制におけるインバータ数削減”，平成 23 年電 気学会全国大会講演論文集，第 5 分冊 (2011), pp. 121-122 